\title{
Code Switching and Code Mixing Among Students Islamic School
}

\author{
Rizki Alawiya* \\ Postgraduate English Department \\ Universitas Mataram \\ Mataram, Indonesia \\ rizkiza13@gmail.com
}

\author{
Untung Waluyo \\ Postgraduate English Department \\ Universitas Mataram \\ Mataram, Indonesia
}

\author{
Henny Soepriyanti \\ Postgraduate English Department \\ Universitas Mataram \\ Mataram, Indonesia
}

\begin{abstract}
This study aims to analyze the types of code switching and code mixing frequently uttered by students of Islamic school, particularly at junior high school and senior high school in East Lombok, Indonesia. This paper is qualitative research, in which the result was analyzed by descriptive analysis using Poplack and Musyken theory. Through the questionnaire administered on 39 respondents of the target population, the researcher got that students of the Islamic school used code switching and code mixing in types of intra-sentential, inter-sentential, insertion, and alternation. The students' reasons in switching and mixing the codes were also described.
\end{abstract}

Keywords - language, code switching, code mixing, Islamic school

\section{INTRODUCTION}

Boarding school or "pesantren" in Indonesia becomes one of places where code switching and code mixing happened often. One of reasons is because students learn foreign language such as English, Arabic, Mandarin, or other languages. But in Lombok, Indonesia, more students of Islamic boarding school learn English and Arabic. Generally, English in education becomes a subject that must be learnt for students in junior high school and senior high school and it was stated in Indonesian curriculum, meanwhile Arabic is learnt only by students who are in Islamic school setting.

Furthermore, those languages are practiced in daily conversions among students and between students to teachers. Some schools encourage their students use a hundred percent communication in English and Arabic; they usually have a program named as English day or Arabic day, but for other schools, students are free to use which languages they want to. The students in this type (first type) of school usually switch or mix the languages; English-Indonesia, Arabic-Indonesia, or English-Arabic. Of two types of schools, this paper will examine the second issue where the languages are switched and mixed.

Based on what stated above, this study was focused on analyzing code switching and code mixing of Islamic school students by using the theories of code switching proposed by Poplack, Fischer, and Muysken [1].

The aim of this study were; (1) to know what language is usually used by students at Islamic school, (2) to know what foreign words or expressions that are usually used in interaction, (3) to describe the students' reasons in switching the language.
This research was qualitative research with using case study since it analyzes utterances. In addition, this research conveys the data in words because it is designed to obtain information from the current status of the subject of the research and describes the nature of the study.

\section{A. Definition of Code-Mixing and Code Switching}

According to Poplack "Code-switches will tend to occur at points in discourse where juxtaposition of L1 and L2 elements does not violate a syntactic rule of either language, i.e. at points around which the surface structures of the two languages map onto each other. According to this simple constraint, a switch is inhibited from occurring within a constituent generated by a rule from one language which is not shared by the other." $[1]$

According to Holmes in Iswanto, "Code switching occurs when the speaker shifted their language from one language to another [2]. Code switching is switched essentially between sentences."[2] The third definition explored by Fischer suggests that code switching or intersentential code-alternation occurs when a bilingual speaker uses more than one language in a single utterance above the clause level to appropriately convey his intents.

Code choice or the language in communities where bilingualism or multilingualism is the norm should be analyzed in the context where the speech is produced. According to Fischer, code mixing also called intrasentential code switching or intra-sentential codealternation occurs when speakers use two or more languages below clause level within one social situation. "Patterns of code switching are found to be different from one another because of several distinct processes such as 'insertion', 'alternation' and 'congruent lexicalization'. These three processes correspond to dominant models, and approach [1].

From some definitions above, we can conclude that bilingual speakers change his/her utterances into other languages when they communicate. This change may be involved in one type of code switching and code mixing or involved in all types.

\section{B. Difference Concept between Code-switching and Code-mixing}

When we discuss about the differences between codes switching and code mixing, both of them have the strong similarities, even though it is difficult to find the differences, but with the following explanation, those will help the readers to understand the differences clearly. 
The similarities of the both are just in the function when we use two or more languages as a variant language in speech community. But the differences are in code switching, switch language event or variety of languages by the bilingual because of particular reason and consciously. While code mixing, the use of pieces of another language to one language that is needed, has the function and it is not considered as a wrong or deviation. Like in our country, a bilingual person sometimes slipped a pieces of language in conversation which it can be said he or she did code mixing.

Hymes defined only code-switching as "a common term for alternative use of two or more language, varieties of a language or even speech styles. Meanwhile Maschler defined code mixing or a mixed code as "using two languages such that a third, new code emerges, in which elements from the two languages are incorporated into a structurally definable pattern [3]. To conclude, differences between code-switching and code-mixing are in bellow:

TABLE I. DIFFERENCES BETWEEN CODE-SWITCHING AND CODEMIXING

\begin{tabular}{|l|l|l|}
\hline \multicolumn{1}{|c|}{ Points of View } & Code-switching & Code-mixing \\
\hline $\begin{array}{l}\text { Grammatical items } \\
\text { involved }\end{array}$ & $\begin{array}{l}\text { Sentence and } \\
\text { clause }\end{array}$ & $\begin{array}{l}\text { Phrase, word, } \\
\text { morpheme, phonemes }\end{array}$ \\
\hline Base language & Clear & Sometimes unclear \\
\hline Topics & May change & Maintained \\
\hline Situations & $\begin{array}{l}\text { Formal and } \\
\text { informal }\end{array}$ & More likely informal \\
\hline
\end{tabular}

\section{Types of Code Switching and Code Mixing}

According to Poplack in Martiana $(2013)^{[6]}$ there are three types of code-switching: (1) Intra-sentential code switching; (2) Inter-sentential code switching; and (3) Extra-sentential code switching or tag-switching [4]. Intrasentential code switching occurs when the alternation of certain language used is below sentential boundaries. Appel and Muysken in Yuliana (2015) stated that "intrasentential code-switching is the alternation in a single discourse between two languages, where the switching occurs within a sentence" [5]. According to Bokamba in Yuliana (2015), "Intra-sentential code-switching coincides with code-mixing. Inter-sentential code switching happens whereas people switching the language, Indonesian and English, between sentences or clauses" [5].

Code mixing is a mixing of two languages, usually people do it without a change of topic. Code mixing often occurs within one sentence, one element is spoken in language $\mathrm{A}$ and the rest in language $\mathrm{B}$ or $\mathrm{C}$. In addition, Nababan (1993 as cited in Astuti 2011) said that code mixing is found mainly in informal interactions [6]. In formal situation, the speaker tends to mix it because there is no exact idiom in matrix language (dominant language), so it is necessary to use words or idioms from other language [6]. Types of code mixing:

\section{1) Intra-Sentential Switching / Code Mixing}

This kind of code mixing occurs within a phrase, a clause or a sentence boundary, as when we say: "La adri. Ustadzah, pokoknya minta kita kesana."

\section{2) Intra-Lexical Code Mixing}

This kind of code mixing occurs within a word boundary, such as "I don't now-lah, jalani saja."

\section{3) Involving a Change of Pronunciation}

This kind of code mixing occurs at the phonological level, for instance, the word 'orange' is said to be 'oren' by Indonesian people.

\section{Reason of Code Switching and Code Mixing}

There are various reasons which motivate speakers to employ code switching when interacting with each other. Bilinguals and multilingual use code switching for the following reasons:

- To emphasize a specific point(Baker \& Sert in Iina 2015) [7]

- To substitute a word or a phrase (Baker and Dumanigas. [7]

- The referential function, according to in which a switch occurs because of the "lack of knowledge of one language or lack of facility in that language on a certain subject". Appel and Muysken as citted in Jelena [8].

- Code switching takes place when a point is being reinforced. The expressions are usually used are repetition but in other language or only mention the word that need to reinforce.

- Code switching can also be used to create a comfortable situation.

- Expressing group identity.

- In the case of the expressive function, discussed by Poplack, the speakers switch code in order to express their "mixed identity" [8].

\section{E. Matrix Language And Embeded Language}

Besides what stated above about codes switching and code mixing, in this study, it should be stated about two familiar terms in studying this topic, namely: matrix language (ML) and Embeded languang (EL). The dominant language is called the matrix language, into which elements from the embedded language are inserted. According to Myers-Scotton in Charles [9], “...the participating languages are labelled in the following way. The 'base' language is called the matrix language (ML) and the 'contributing' language (or languages) is called the embedded language (EL)."

\section{METHOD}

To obtain the necessary information, the researcher collected data by using questionnaires distributed to the sample. The population and samples were students of junior and senior high school who stay in dormitory and study at Islamic boarding school, particularly in Lombok Timur, Indonesia. Therefore, the sample of this study was determined by the common behaviour of code switching among the speech community of students in Islamic boarding school and by the judgment of the researcher.

This research involved a qualitative descriptive study that produces descriptive data in the form of words written that taken by students' answers. The data analysis is inherently a language-based analysis. In the first step of this research, data were taken from recapitulation of respondents' answers. Second, the data were transcribed, 
and third, the types of code-mixing and code-switching that occurred were classified. Finally, all data were analyzed by using theory of Muysken (2000) and Poplack (1980), thus we stated any conclusion at the end.

\section{RESULTS AND DISCUSSION}

In accordance to research question, it was found that students in Islamic school usually switched and mixed their communication language in English and Arabic, but based on the data taken, they used bahasa Indonesia as matrix language, Arabic and English as embedded language with the majority of students $(59 \%)$ who use both as embedded language. The question was "Which foreign language do you usually practice fully or mix in your school; English, Arabic, or both?'

We also got some popular words that are typically used by them in communication whether with their friends or their teacher. The question was, "What words that you usually hear/use in mixing the language? You may choose more than one! "From the data, we found the most popular word was "afwan", followed by "sorry", "matbakh", "hammam", "sakan". The percentages were $82.1 \%, 27 \%$, $23 \%, 22 \%$, and $20.5 \%$ respectively which a students might choose more than one word. From the data, we can conclude that in Islamic school setting, students used Arabic as embedded language frequently than English. From five words above, only one word was in English which the most popular, that was "sorry" and other four words are Arabic.

The third question about the reason why they mix and switch the language, in which students may choose more than one choices and they may add other answer. Based on the results compared to theory and prior research about this topic, $32(82.1 \%)$ of them say that they switch or mix the language because they cannot speak fully in target language at school (Arabic and English), thus mixing or switching is always listened every day. This reason reflects to what Baker et al. as cited in Iina said that, "Code switching can take place when a word or a phrase from a matrix language or an embedded language is substituted for accomplishing communication goals [10]

The second reason why they did code switching and mixing is that they feel comfortable in interacting because this is usually to expresses group identity; the percentage was $69.2 \%$. Code switching and code mixing are also used to express group identity. The way of communication of Islamic school student are obviously different from the other groups. In other words, the way of communication of one community is different from the people who are out of that community and it usually make they feel comfortable.

One of the lowest percentage in the bar chart is to emphasize or reinforcement. $15.4 \%$. Baker et al. in Iina [7] said that code switching can take place if speakers would like to emphasize a discussed point, or to make a central issue in a discussed point. The last but not least is the sentences or expression that usually practiced in daily communication is in the following figure (here is just some sentences from the sample, not all are displayed):
TABLE II. EXPRESSION THAT USUALLY PRACTICED IN DAILY COMMUNICATION

\begin{tabular}{|c|c|c|}
\hline Expression & $\begin{array}{l}\text { Code } \\
\text { Mixing }\end{array}$ & $\begin{array}{l}\text { Code } \\
\text { Switching }\end{array}$ \\
\hline Sorrykmarensayandakdatangkesekolah & Insertion & $\begin{array}{l}\text { Intra- } \\
\text { sentential }\end{array}$ \\
\hline Besokadaikhtibar & Insertion & $\begin{array}{l}\text { Intra- } \\
\text { sentential }\end{array}$ \\
\hline Na'ambu guru & Insertion & $\begin{array}{l}\text { Intra- } \\
\text { sentential }\end{array}$ \\
\hline Excuse me, izinkebelakang miss & Insertion & $\begin{array}{l}\text { Intra- } \\
\text { sentential }\end{array}$ \\
\hline $\begin{array}{l}\text { Afwanustadzah, sayanggak tau } \\
\text { adatugas }\end{array}$ & Insertion & $\begin{array}{l}\text { Intra- } \\
\text { sentential }\end{array}$ \\
\hline Ada muhaddasahnantimalam & Insertion & $\begin{array}{l}\text { Intra- } \\
\text { sentential }\end{array}$ \\
\hline Kenapaantikesakan? & Insertion & $\begin{array}{l}\text { Intra- } \\
\text { sentential }\end{array}$ \\
\hline Siapamauikutkemaqsof? & Insertion & $\begin{array}{l}\text { Intra- } \\
\text { sentential }\end{array}$ \\
\hline Please deh, temeninaku. & Insertion & $\begin{array}{l}\text { Intra- } \\
\text { sentential }\end{array}$ \\
\hline La adri. Kamuaja yang tau & Insertion & $\begin{array}{l}\text { Intra- } \\
\text { sentential }\end{array}$ \\
\hline Izinkehammamustadz. & Insertion & $\begin{array}{l}\text { Intra- } \\
\text { sentential }\end{array}$ \\
\hline Ma hazaUstadz? Barulihat & Insertion & $\begin{array}{l}\text { Intra- } \\
\text { sentential }\end{array}$ \\
\hline You are so handsome ustadz & Alternation & $\begin{array}{l}\text { Intra- } \\
\text { sentential }\end{array}$ \\
\hline Ayolet's go! & Insertion & $\begin{array}{l}\text { Intra- } \\
\text { sentential }\end{array}$ \\
\hline Total & $\begin{array}{l}\text { Insertion= } \\
97.3 \% \\
\text { Alternation } \\
=2.7 \%\end{array}$ & $\begin{array}{l}\text { Intra- } \\
\text { sentential= } \\
100 \%\end{array}$ \\
\hline
\end{tabular}

From table 2 above, typically students use insertion in code mixing, which insert embedded language to matrix language (bahasa Indonesia) and intra-sentential in code switching, because according to Apeal et al., intrasentential occurs in a single discourse between two languages, where the switching occurs within a sentence. Only one is classified in alteration because that is complete sentence not a phrase or word in embedded language.

\section{CONCLUSION}

Code-switching is a term in linguistics referring to using more than one language or variety in utterances. This research revealed the code switching and code mixing that usually happened at students of junior and senior high school who stay in dormitory at Islamic school setting. The utterances were then classified into some types of code mixing and code switching.

From all data taken, the students used Arabic expressions more than English expressions. In types of code switching, students used inter-sentential which the sentences typically uttered in simple sentence. In addition, in code mixing, almost all data were classified into insertion. The result is proportional to existing theory such as theory proposed by Poplack, Musyken, Gumperz, and other prior researchers. 


\section{REFERENCES}

[1] P. Muysken and P. C. Muysken, Bilingual speech: A typology of code-mixing. Cambridge University Press, 2000.

[2] A. I. Wibowo, I. Yuniasih, and F. Nelfianti, "Analysis of Types Code Switching and Code Mixing By The Sixth President of Republic Indonesia's Speech at The National of Independence Day," Progress. J., vol. 12, no. 2, pp. 77-86, 2017.

[3] M. T. Putnam, Studies on German-language islands, vol. 123. John Benjamins Publishing, 2011.

[4] T. Martiana, "Examining Code-Switching Practices in Hilman Hariwijaya's Makhluk Manis dalam Bis and Bunga untuk Poppi," Passage, vol. 1, no. 1, pp. 9-20.

[5] N. Yuliana, A. R. Luziana, and P. Sarwendah, "Code-mixing and code-switching of Indonesian celebrities: A comparative study," Ling. Cult., vol. 9, no. 1, pp. 47-54, 2015.

[6] D. A. Cakrawarti, "Analysis of code switching and code mixing in the teenlit Canting Cantiq by Dyan Nuranindya." University of Diponegoro, 2011.

[7] I.-M. Aukongo, "The role of code switching as a communicative strategy between Outapi residents and public officials.” 2015.

[8] J. Brezjanovic-Shogren, "Analysis of code-switching and code-mixing among bilingual children: two case studies of Serbian-English language interaction." Wichita State University, 2011

[9] C. Coulter, C. Michael, and L. Poynor, "Storytelling as pedagogy: An unexpected outcome of narrative inquiry," Curric. Inq., vol. 37, no. 2, pp. 103-122, 2007.

[10] T. Sutikno, L. Handayani, D. Stiawan, M. A. Riyadi, and I. M. I. Subroto, "WhatsApp, viber and telegram: Which is the best for instant messaging?," Int. J. Electr. Comput. Eng., vol. 6, no. 3,2016 . 